\title{
KETANGGUHAN WILAYAH PESISIR SELATAN PROVINSI DAERAH ISTIMEWA YOGYAKARTA TERHADAP BAHAYA BENCANA TSUNAMI
}

\author{
Mega Kusuma Dewi ${ }^{1}$, Doddy Aditya Iskandar ${ }^{1}$ \\ ${ }^{1}$ Magister Teknik Perencanaan Wilayah dan Kota, Fakultas Teknik, Universitas Gadjah Mada, Yogyakarta, Indonesia \\ ${ }^{1}$ Email : meygakusumadewi@mail.ugm.ac.id \\ DOI: 10.35472/jppk.v1i1.461
}

\begin{abstract}
The southern coastal region of the Special Region of Yogyakarta (DIY) has a high vulnerability to the risk of tsunami. This disaster risk is certainly endangering the people who live in this area. In addition, this risk can also be a factor that hinders development in the DIY's coastal area. Therefore, in order to reduce the negative impacts, this area must be resilient to a tsunami disaster. This study is an effort to measure the regional resilience against the tsunami risk in 13 sub-districts on the south coast of DIY. The measurement uses a calculation method adapted from the theory of spring elasticity. The finding demonstrates subdistricts in the SRY have low to moderate level of resilience to tsunami disaster.
\end{abstract}

Kata Kunci: Ketangguhan, Bencana, Tsunami

\section{A. PENDAHULUAN}

Wilayah pesisir Provinsi Daerah Istimewa Yogyakarta (DIY) merupakan bagian dari pesisir selatan Pulau Jawa yang rentan terhadap bahaya tsunami. Hal ini salah satunya disebabkan oleh adanya celah seismik (seismic gap) di kawasan tersebut yang dapat menimbulkan gelombang tsunami dengan ketinggian hingga 10 meter (Prasetya \& Imamura, 2010). Lebih jauh, sebuah studi mengungkap kemungkinan terjadinya gempa berkekuatan sedang hingga kuat sebanyak 1-10 kali dalam setahun yang bisa memicu gelombang tsunami di pesisir selatan Pulau Jawa (Kongko \& Hidayat, 2020).

Kajian dari BNPB menemukan bahwa Kabupaten Kulon Progo, Bantul, dan Gunungkidul sangat rentan terhadap risiko bencana tsunami. Berdasarkan kajian dari BNPB (2019a), ketiga kabupaten ini memiliki indeks risiko bencana tsunami yang tergolong dalam kelas risiko tinggi. Lebih jauh, BNPB (2019b) juga menemukan bahwa setidaknya ada 25 desa/kelurahan di tiga kabupaten tersebut yang berada dalam kawasan rawan tsunami, dengan tiga di antaranya termasuk dalam kawasan rawan bencana tsunami kelas bahaya tinggi, dan sisanya (22 desa/kelurahan) berada dalam kawasan dengan kelas bahaya sedang. Selain itu, bencana tsunami di Provinsi DIY diperkirakan bisa menimbulkan korban sebanyak 48.271 jiwa, kerusakan fisik senilai 90 miliar rupiah dan kerugian ekonomi sebanyak 1,4 triliun rupiah (BNPB, 2016).

Beberapa kajian lain juga menemukan adanya bahaya tsunami di kawasan pantai selatan Provinsi DIY. Marfai et al. (2019) melakukan pemetaan area tergenang dan perhitungan estimasi kerugian tsunami di kawasan Pantai Drini Gunungkidul. Hasil pemetaan menunjukkan luasan area yang rentan terdampak oleh bencana tsunami di 
kawasan ini adalah 7,71 ha pada skenario inundasi 4 meter hingga 31,56 ha pada skenario inundasi 12 meter. Penggunaan lahan yang paling terdampak adalah pertanian dan kawasan perdagangan di Pantai Drini. Kemudian, sebuah simulasi dan perhitungan yang dilakukan oleh Kongko dan Hidayat (2014) mengidentifikasi risiko tsunami di kawasan pesisir selatan Provinsi DIY khususnya di Kabupaten Bantul. Hasil penelitian ini menemukan bahwa kejadian gempa dengan kekuatan magnitudo 8,2 dapat menyebabkan tsunami setinggi 6 meter dan menggenangi area seeluas $20 \mathrm{~km}^{2}$.

Berbagai kajian di atas menunjukkan eksistensi risiko bencana tsunami di pesisir selatan Provinsi DIY. Risiko bencana ini tentunya bisa menimbulkan kerusakan infrastruktur, kerugian ekonomi maupun sosial (Yavuz et al., 2020). Lebih jauh, pada tingkat tertentu, risiko bencana ini juga bisa menjadi faktor yang menghambat pertumbuhan dan pembangunan suatu wilayah. Oleh karena itu, Benson \& Clay (2004) mengemukakan bahwa untuk meminimalisasi dampak negatif yang ditimbulkan, risiko bencana harus dipertimbangkan dalam proses perumusan program dan kebijakan pembangunan. Selain itu, upaya lain yang bisa dilakukan untuk mengurangi kerusakan yang ditimbulkan oleh suatu bencana adalah dengan menciptakan komunitas yang memiliki ketangguhan terhadap bencana (Levy \& Gopalakrishnan, 2005).

United Nations International Strategy for Disaster Reduction (UNISDR, 2009) mendefinisikan ketangguhan bencana sebagai kemampuan dari sebuah sistem, komunitas atau masyarakat untuk menghadapi suatu kejadian bencana dan untuk segera pulih dari dampak negatif yang ditimbulkannya. Dalam kerangka pengurangan risiko bencana, meningkatkan ketangguhan bencana merupakan suatu upaya yang penting untuk dilakukan guna melindungi suatu wilayah beserta masyarakat dan aset yang ada di dalamnya (National Emergency Management Committee, 2009; UNISDR, 2015). Kemudian, untuk meningkatkan ketangguhan suatu wilayah terhadap bencana, maka pengukuran terhadap ketangguhan bencana itu sendiri juga perlu dilakukan. Tujuan dari pengukuran ini adalah untuk mengidentifikasi tingkat atau status ketangguhan yang dimiliki oleh suatu komunitas atau wilayah. Selain itu, pengukuran ketangguhan ini juga merupakan salah satu alat bagi pembuat kebijakan untuk merumuskan intervensi yang paling tepat dan efisien dalam upayanya meningkatkan ketangguhan wilayah dan masyarakatnya terhadap bencana (Béné, 2013; Parsons et al., 2016).

Tujuan dari penelitian ini adalah untuk mengukur ketangguhan kecamatan di pesisir selatan Provinsi DIY terhadap bencana alam tsunami. Metode pengukuran ketangguhan yang dikembangkan oleh Pusphalal \& Suzuki (2020), yang secara spesifik mengukur ketangguhan suatu wilayah terhadap ancaman bencana tsunami, digunakan dalam studi ini. Di akhir penelitian, tingkat ketangguhan terhadap bencana tsunami dari tiap kecamatan yang ada di Pantai Selatan Provinsi DIY bisa diketahui. Selain itu, indikatorindikator yang mempengaruhi tingkat ketangguhan tersebut juga bisa diidentifikasi sehingga bisa menjadi masukan bagi pemerintah Provinsi DIY dalam menentukan fokus program dan kebijakan untuk meningkatkan ketangguhan wilayah pesisirnya terhadap bencana tsunami. 


\section{B. METODE PENELITIAN}

\section{Lokasi Penelitian}

Wilayah yang menjadi fokus amatan dan analisis dalam studi ini adalah 13 kecamatan pesisir di Provinsi DIY (Gambar 1.). Rinciannya adalah empat kecamatan di Kabupaten Kulon Progo, tiga di Kabupaten Bantul, dan enam di Kabupaten Gunung Kidul. Kecamatan pesisir dipilih karena resiko bencana tsunami paling tinggi berada pada yang wilayah yang langsung berbatasan dengan laut.

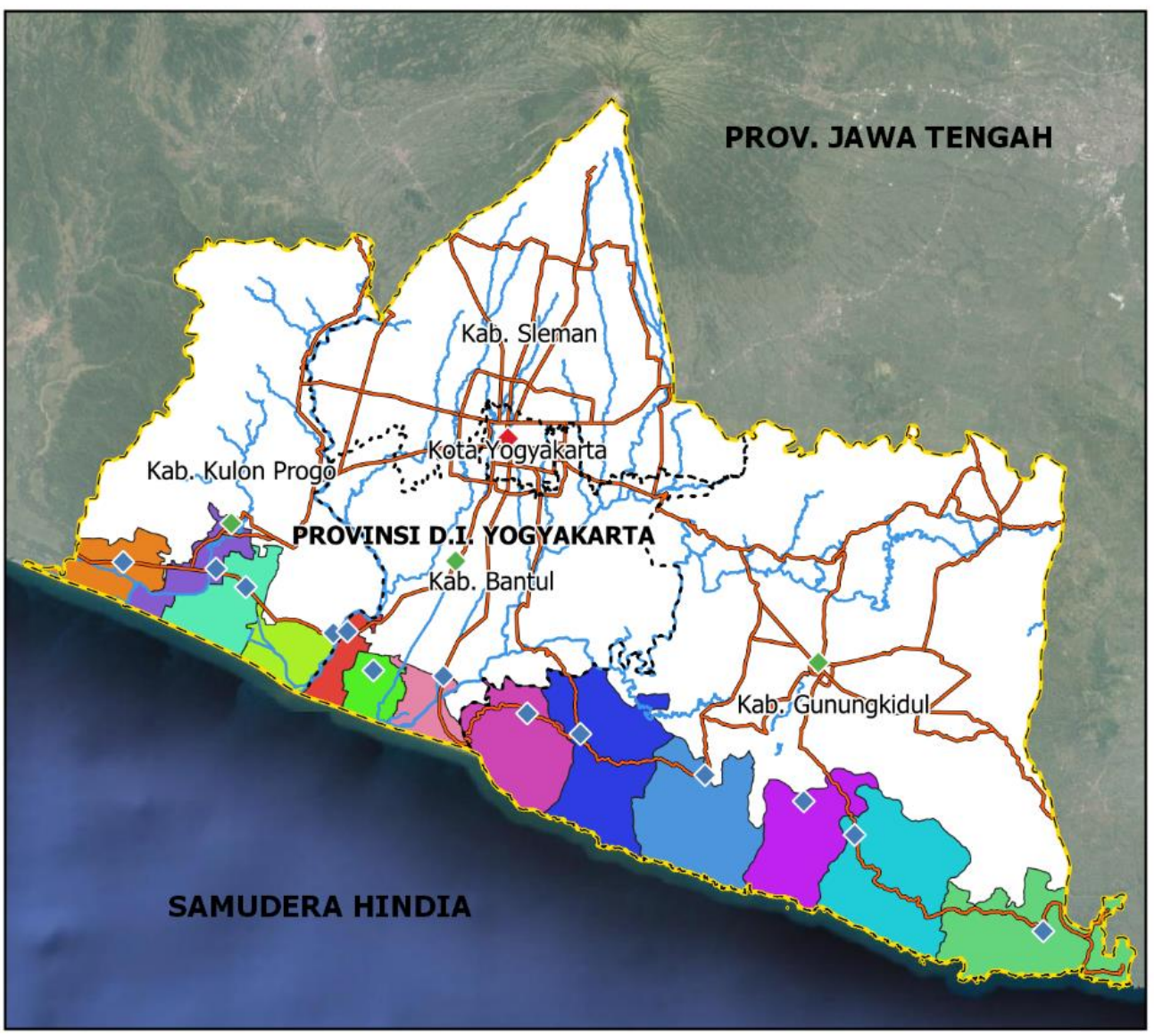

PETA ADMINISTRASI

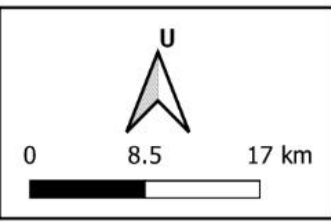

\begin{tabular}{|l|}
\hline KETERANGAN \\
- - Batas Provinsi \\
- - Batas Kabupaten/Kota \\
Jalan \\
\hline Sungai \\
Kantor Gubernur \\
Kantor Bupati \\
Kantor Kecamatan \\
Kecamatan \\
\hline Temon \\
Wates \\
Panjatan \\
\hline Galur \\
Srandakan \\
Sanden \\
Kretek \\
Purwosari \\
Panggang \\
Saptosari \\
Tanjungsari \\
Tepus \\
Girisubo \\
\end{tabular}

Sumber: Penulis, 2021

Gambar 1. Peta Administrasi Wilayah Penelitian

Luas wilayah dan panjang garis pantai dari tiap kecamatan dalam penelitian ini bervariasi (Tabel 1.). Kecamatan dengan luas wilayah terbesar adalah Kecamatan Tepus di Kabupaten Bantul, yaitu 104,94km2, sedangkan kecamatan yang mempunyai garis pantai terpanjang adalah Kecamatan Girisubo di Kabupaten Gunung Kidul, yakni 27,45km. Kecamatan Srandakan di Kabupaten Bantul menjadi kecamatan dengan luas wilayah terkecil $(12,32 \mathrm{~km} 2)$ dan garis pantai terpendek $(3,59 \mathrm{~km})$. 
Tabel 1

Kecamatan di Wilayah Pesisir Selatan Provinsi DIY

\begin{tabular}{|l|l|c|c|}
\hline Kabupaten & Kecamatan & Luas Wilayah $\left.\mathbf{( k m}^{\mathbf{2}}\right)$ & Panjang Garis Pantai (km) \\
\hline \multirow{4}{*}{ Kulon Progo } & Temon & 36,3 & 8,76 \\
\cline { 2 - 4 } & Wates & 32 & 3,8 \\
\cline { 2 - 4 } & Panjatan & 44,59 & 7,33 \\
\cline { 2 - 4 } & Galur & 32,91 & 6,06 \\
\hline \multirow{4}{*}{ Bantul } & Srandakan & 12,32 & 3,59 \\
\cline { 2 - 4 } & Sanden & 23,16 & 3,99 \\
\cline { 2 - 4 } & Kretek & 26,77 & 7,53 \\
\hline \multirow{5}{*}{ Gunung Kidul } & Purwosari & 71,76 & 9,02 \\
\cline { 2 - 4 } & Panggang & 99,8 & 13,3 \\
\cline { 2 - 4 } & Saptosari & 87,83 & 16,24 \\
\cline { 2 - 4 } & Tanjungsari & 71,63 & 9,36 \\
\cline { 2 - 4 } & Tepus & 104,94 & 14,4 \\
\cline { 2 - 4 } & Girisubo & 94,57 & 27,45 \\
\hline
\end{tabular}

Sumber: BPS, 2020

\section{Metode Analisis Ketangguhan Wilayah Terhadap Bencana Tsunami}

Analisis ketangguhan wilayah dalam studi ini menggunakan metode yang dikembangkan oleh Pushpalal dan Suzuki (2020). Metode ini dinilai relevan untuk digunakan pada penelitian ini karena secara spesifik mengukur ketangguhan wilayah terhadap bencana alam tsunami. Selain itu, metode ini juga memiliki keunikan karena diadaptasi dari teori elastisitas pegas dalam ilmu fisika. Teori elastisitas pegas menyebutkan bahwa ketika sebuah pegas diberikan sebuah gaya, maka pegas tersebut akan memanjang/memendek secara proporsional sesuai dengan besar gaya yang diberikan. Lalu, ketika gaya tersebut dihilangkan, maka pegas akan kembali ke bentuk semula.

Dalam metode ini, sebuah wilayah yang tangguh diibaratkan sebagai sebuah pegas yang elastis dan bencana diibaratkan sebagai beban yang memberikan gaya pada pegas tersebut. Ketika terjadi sebuah bencana, maka wilayah yang tangguh seharusnya bisa menghadapi dan beradaptasi dengan bencana tersebut. Kemudian, setelah terjadinya bencana, wilayah yang tangguh juga seharusnya dapat segera kembali dalam kondisi sebelum terjadinya bencana.

Ada tiga dimensi ketangguhan terhadap bencana tsunami yang dianalisis, yaitu: kapasitas lokasi/onsite capacity (OC), kemampuan masyarakat untuk bertahan/instantaneous survivability (IS), dan kemampuan pemulihan/recovery potentiality (RC). Setiap dimensi dibagi lagi menjadi sub-dimensi yang kemudian masing-masing sub-dimensi diukur melalui beberapa indikator. Secara keseluruhan, ada 13 indikator yang digunakan dalam perhitungan indeks ketangguhan kedua ini (Tabel 2). Nilai tiap indikator berada pada rentang 0 hingga 1 . Indikator yang nilainya tidak berbentuk rasio atau persentase distandarisasi dengan skema perhitungan minimalmaksimal. Kemudian, indikator yang jika nilainya semakin besar justru akan memperkecil skor ketangguhan, nilai dari indikator tersebut diinversi terlebih dahulu. 
Tabel 2

Dimensi, sub-dimensi, dan indikator pengukuran ketangguhan efektif terhadap

bencana tsunami

\begin{tabular}{|c|c|c|c|}
\hline Dimensi & Sub-dimensi & Indikator & Deskripsi \\
\hline \multirow[t]{3}{*}{$\begin{array}{l}\text { Kapasitas lokasi } \\
\text { (OC) }\end{array}$} & Infrastruktur & Panjang jalan & $\begin{array}{l}\text { Standarisasi minimal maksimal } \\
\text { dari panjang jalan per } \mathrm{km}^{2}\end{array}$ \\
\hline & \multirow[t]{2}{*}{ Kondisi geografis } & Ketinggian wilayah & $\begin{array}{l}\text { Standarisasi minimal maksimal } \\
\text { dari ketinggian wilayah dalam } \\
\text { area penyangga } 200 \text { meter dari } \\
\text { bibir pantai }\end{array}$ \\
\hline & & Jarak dari laut & $\begin{array}{l}\text { Standarisasi minimal maksimal } \\
\text { jarak titik tengah wilayah } \\
\text { (centroid) dari bibir pantai }\end{array}$ \\
\hline \multirow{5}{*}{$\begin{array}{l}\text { Kemampuan } \\
\text { masyarakat } \\
\text { bertahan (IS) }\end{array}$} & \multirow[t]{4}{*}{ Struktur kependudukan } & Kepadatan penduduk & $\begin{array}{l}\text { Standarisasi minimal maksimal } \\
\text { dari inversi kepadatan penduduk }\end{array}$ \\
\hline & & $\begin{array}{l}\text { Komposisi penduduk } \\
\text { berdasarkan jenis } \\
\text { kelamin }\end{array}$ & Rasio jenis kelamin \\
\hline & & $\begin{array}{l}\text { Penduduk usia } \\
\text { produktif }\end{array}$ & $\begin{array}{l}\text { Rasio jumlah penduduk usia } \\
\text { produktif (15-64 } \\
\text { terhadap jumlah } \\
\text { keseluruhan }\end{array}$ \\
\hline & & $\begin{array}{l}\text { Penduduk } \\
\text { berkebutuhan khusus }\end{array}$ & $\begin{array}{l}\text { Standarisasi minimal-maksimal } \\
\text { dari inversi jumlah penduduk } \\
\text { berkebutuhan khusus }\end{array}$ \\
\hline & $\begin{array}{l}\text { Kemudahan untuk } \\
\text { menyelamatkan diri }\end{array}$ & Kelerengan wilayah & $\begin{array}{l}\text { Standarisasi minimal-maksimal } \\
\text { dari inversi rata-rata kelerengan } \\
\text { wilayah }\end{array}$ \\
\hline \multirow[t]{5}{*}{$\begin{array}{l}\text { Kemampuan } \\
\text { Pemulihan (RP) }\end{array}$} & Integritas sosial & $\begin{array}{l}\text { Komposisi penduduk } \\
\text { berdasarkan agama }\end{array}$ & $\begin{array}{l}\text { Persentase penduduk yang } \\
\text { beragama mayoritas }\end{array}$ \\
\hline & Kapasitas pendidikan & Tingkat pendidikan & $\begin{array}{l}\text { Rasio jumlah penduduk dengan } \\
\text { pendidikan terakhir SMA atau } \\
\text { lebih terhadap jumlah penduduk } \\
\text { dengan pendidikan terakhir } \\
\text { SMP atau di bawahnya }\end{array}$ \\
\hline & \multirow[t]{2}{*}{ Kapasitas ekonomi } & Tingkat kemiskinan & $\begin{array}{l}\text { Persentase penduduk yang tidak } \\
\text { termasuk dalam kategori } \\
\text { penduduk miskin }\end{array}$ \\
\hline & & $\begin{array}{l}\text { Penduduk } \\
\text { bekerja }\end{array}$ & $\begin{array}{l}\text { Rasio jumlah penduduk bekerja } \\
\text { terhadap jumlah penduduk } \\
\text { keseluruhan }\end{array}$ \\
\hline & Fasilitas kesehatan & Jumlah dokter & $\begin{array}{l}\text { Jumlah dokter per } \\
\text { penduduk }\end{array}$ \\
\hline
\end{tabular}

Sumber: Penulis, 2021; diadaptasi dari Pusphalal dan Suzuki (2020)

Nilai untuk tiap indikator, selanjutnya digunakan untuk menghitung nilai subdimensi. Perhitungan sub-dimensi dilakukan dengan menjumlahkan nilai indikator yang selanjutnya dibagi dengan jumlah indikator pada sub-dimensi tersebut. Kemudian, dari hasil perhitungan sub-dimensi, dilakukan perhitungan dimensi ketangguhan dengan prinsip yang sama, yaitu nilai tiap sub-dimensi dijumlahkan lalu dibagi dengan jumlah sub-dimensi pada dimensi tersebut. Dari hasil perhitungan dimensi ketangguhan ini, 
selanjutnya bisa didapatkan nilai ketangguhan efektif terhadap bencana tsunami dengan Rumus (1) di bawah ini. Nilai ketangguhan efektif ada dalam rentang 0-1.

$$
R E F=\frac{\frac{4}{9} O C(I S+R P+1)(O C+I S+1)}{(O C+I S+R P+1)+\frac{4}{9} O C(I S+R P+1)}
$$

Keterangan:

$\mathrm{REF}=$ Ketangguhan Efektif Terhadap Tsunami

$\mathrm{OC}=$ kapasitas lokasi

IS = kemampuan masyarakat untuk bertahan

$\mathrm{RP}=$ kemampuan pemulihan

\section{HASIL DAN PEMBAHASAN}

Hasil analisis menunjukkan bahwa nilai ketangguhan efektif kecamatan pesisir Provinsi DIY berada dalam rentang nilai 0,16 hingga 0,62. Kecamatan Wates Kabupaten Kulon Progo menjadi kecamatan dengan nilai ketangguhan tertinggi yaitu 0,62 ; sedangkan Kecamatan Girisubo Kabupaten Gunungkidul memiliki nilai terendah sebesar 0,16 .

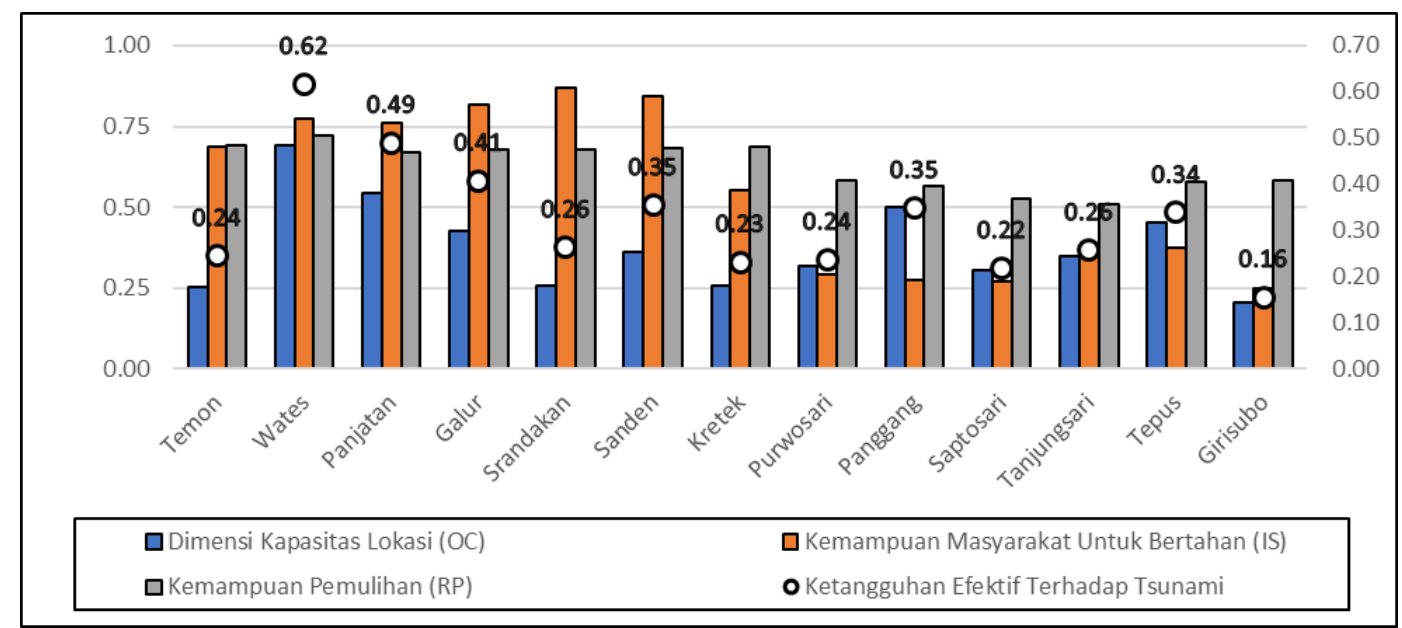

Sumber: Penulis, 2021

Gambar 2. Grafik nilai dimensi dan ketangguhan efektif wilayah terhadap tsunami kecamatan pesisir Provinsi DIY

Apabila dibuat klasifikasi, ketangguhan efektif terhadap tsunami dari tiap kecamatan di pesisir selatan Provinsi DIY berada pada tingkat sangat rendah hingga sedang (Gambar 3.). Tiga pembagian dapat dibuat untuk menentukan karakter ketangguhan wilayah kecamatan di pesisir pantai selatan DIY. Nilai ketangguhan 0-0,25 menjadi tingkat ketangguhan sangat rendah. Ada lima kecamatan yang masuk dalam kelompok ini, yaitu Kecamatan Girisubo, Saptosari, dan Purwosari (Kabupaten Gunungkidul); Kecamatan Kretek (Kabupaten Bantul); dan Kecamatan Temon (Kabupaten Kulon Progo). Kelompok kedua adalah tingkat ketangguhan efektif rendah dengan nilai 0,26-0,50. Sebagian besar 
kecamatan pesisir dalam penelitian ini, yaitu tujuh kecamatan (Galur, Panjatan, Sanden, Srandakan, Tanjungsari, Tepus, Purwosari); termasuk dalam kelompok kedua ini. Kelompok ketiga adalah kelompok dengan tingkat ketangguhan sedang (nilai indeks $0,51-0,75)$. Hanya ada satu kecamatan yang masuk dalam kelompok ini, yaitu Kecamatan Wates Kabupaten Kulon Progo.
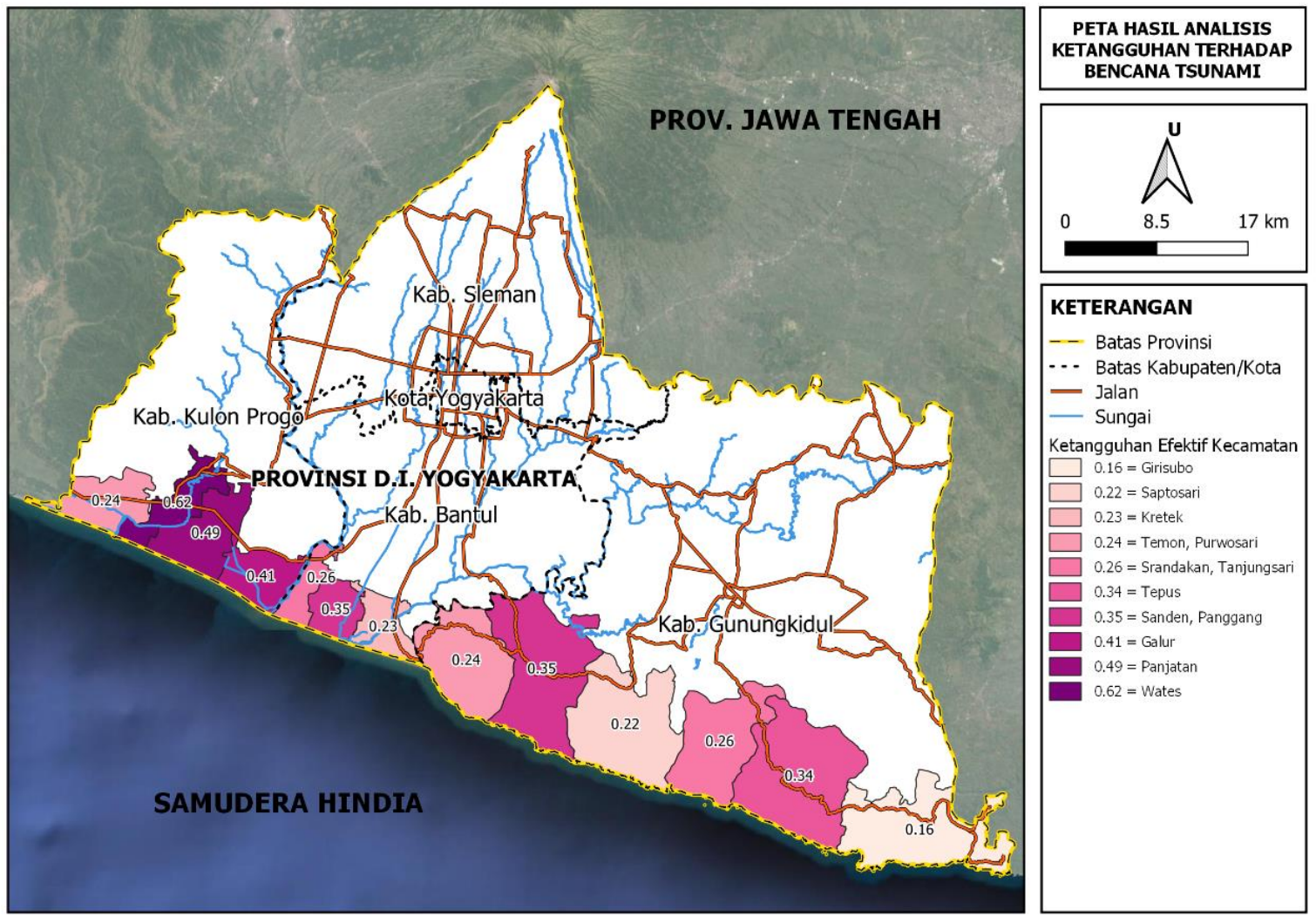

Sumber: Penulis, 2021

Gambar 3. Peta hasil analisis ketangguhan wilayah terhadap bencana tsunami

Pada dimensi ketangguhan kapasitas lokasi, jaringan jalan menjadi indikator yang berpengaruh. Hal ini dapat dilihat pada Kecamatan Wates yang memiliki nilai indikator jaringan jalan paling tinggi sehingga nilai ketangguhan dimensi kapasitas lokasi (OC) pada kecamatan ini juga tertinggi dibandingkan dengan kecamatan lainnya (Gambar 4.). Nilai indikator jaringan jalan yang tinggi membuat ketangguhan suatu wilayah terhadap bencana tsunami juga semakin tinggi. Hal ini dikarenakan jaringan jalan merupakan infrastruktur yang penting dalam proses evakuasi sebelum terjadinya bencana dan penyaluran bantuan setelah terjadinya bencana (Cutter et al., 2010; Kusumastuti et al., 2014; Syam, 2016; Rifat \& Liu, 2020). Dalam konteks bencana tsunami, jaringan jalan sebagai jalur evakuasi yang baik harus bebas dari hambatan, aman dari benda-benda yang dapat menimpa diri, layak dilewati dan kurang lebih memiliki lebar 10 meter (Syam, 2016).

Namun, di sisi lain, jaringan jalan juga bisa menjadi bagian dari komponen kerentanan dari suatu kejadian bencana. Hal ini terjadi ketika jaringan jalan di suatu wilayah terlalu padat, maka ketika terjadi bencana, resiko timbulnya kerusakan dan 
kerugian infrastruktur jalan di wilayah tersebut menjadi semakin tinggi (Cai et al., 2016). Resiko kerugian ini akan semakin besar jika infrastruktur jalan tersebut tidak direncanakan dan dibangun dengan baik (Bahena-Ayala et al., 2021).

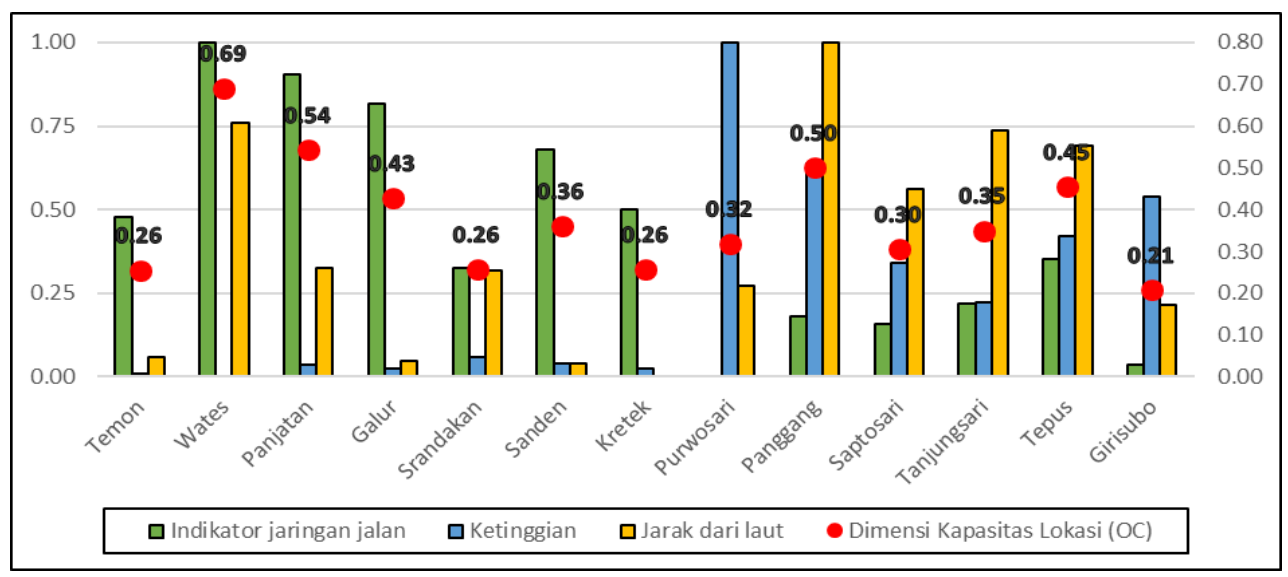

Sumber: Penulis, 2021

Gambar 4. Nilai indikator ketangguhan dimensi kapasitas lokasi

Selanjutnya, hasil analisis menunjukkan bahwa indikator kepadatan penduduk berpengaruh positif pada nilai ketangguhan dimensi IS pada suatu kecamatan (Gambar 5.). Hal ini dapat dilihat pada Kecamatan Srandakan. Kecamatan ini memiliki nilai indikator kepadatan penduduk yang paling tinggi sehingga nilai ketangguhan dimensi IS di kecamatan ini juga tertinggi dibandingkan dengan wilayah lainnya.

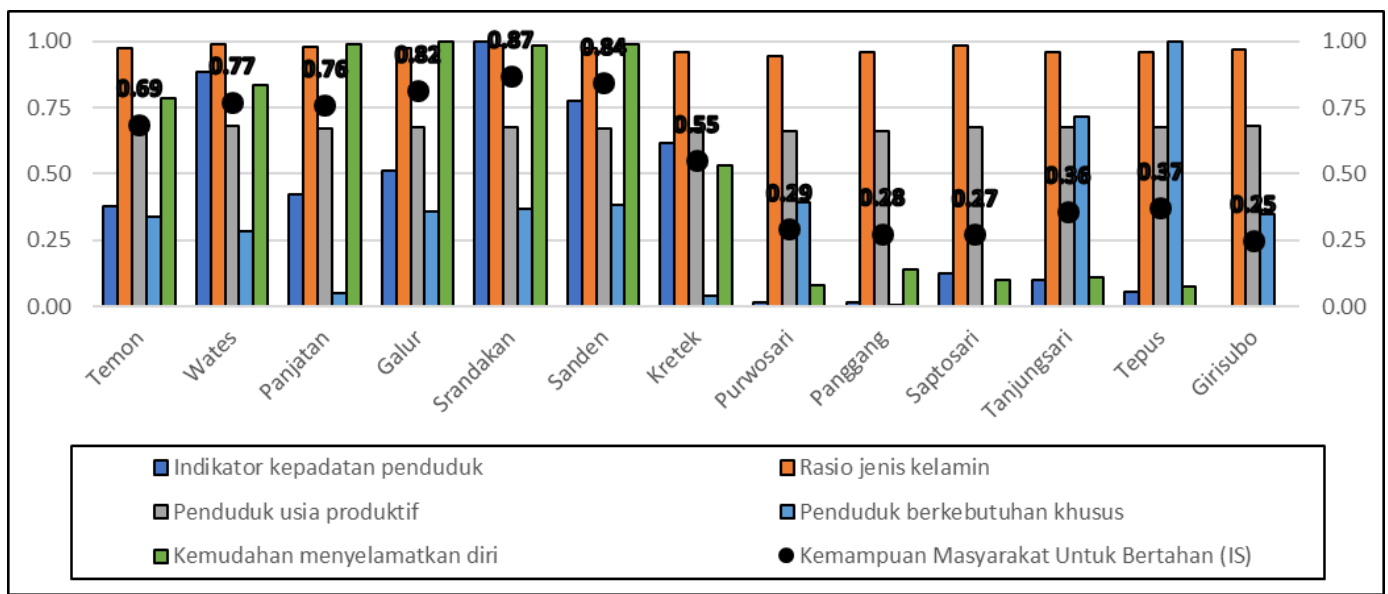

Sumber: Penulis, 2021

Gambar 5. Nilai indikator ketangguhan dimensi kemampuan masyarakat untuk bertahan

Dalam metode analisis yang dipakai pada studi ini, kepadatan penduduk dilihat sebagai salah satu komponen yang meningkatkan ketangguhan suatu wilayah terhadap bencana. Hal ini berlaku apabila penduduk di wilayah tersebut memiliki kesadaran yang tinggi terhadap resiko bencana (Imperiale \& Vanclay, 2016) dan mempunyai kepedulian sosial terhadap sesama yang juga tinggi (Norris et al., 2008; Bikstra et al., 2010). Akan tetapi, seringkali kepadatan penduduk justru menjadi komponen yang mengurangi tingkat 
ketangguhan terhadap bencana. Paramesti (2011) menemukan bahwa semakin padat penduduk maka semakin besar resiko bencana yang mungkin terjadi. Saat terjadi bencana alam, semua akan berbondong-bondong pergi mencari jalan keluar untuk cepat sampai ke tempat evakuasi. Jika penduduk terlalu padat maka kasus jalur evakuasi macet seperti pada kejadian bencana alam tsunami di Aceh dan di Palu bisa terjadi. Jika jarak menuju shelter evakuasi jauh, maka risiko timbulnya banyak korban jiwa semakin besar. Lebih jauh, jumlah penduduk di dunia yang terus bertambah justru membuat semakin banyak penduduk yang bertempat tinggal di kawasan rawan bencana (Xu et al., 2020; Oktari et al., 2020).

Indikator yang berpengaruh pada nilai ketangguhan dimensi kemampuan pemulihan (RP) adalah tingkat pendidikan. Kecamatan pesisir di Kabupaten Gunungkidul memiliki nilai indikator tingkat pendidikan yang lebih rendah dibandingkan dengan kecamatan lain dalam penelitian ini . Hal ini menjadi salah satu faktor yang membuat kecamatan di Gunungkidul memiliki skor ketangguhan dimensi kemampuan pemulihan yang juga lebih rendah dibandingkan yang lainnya.

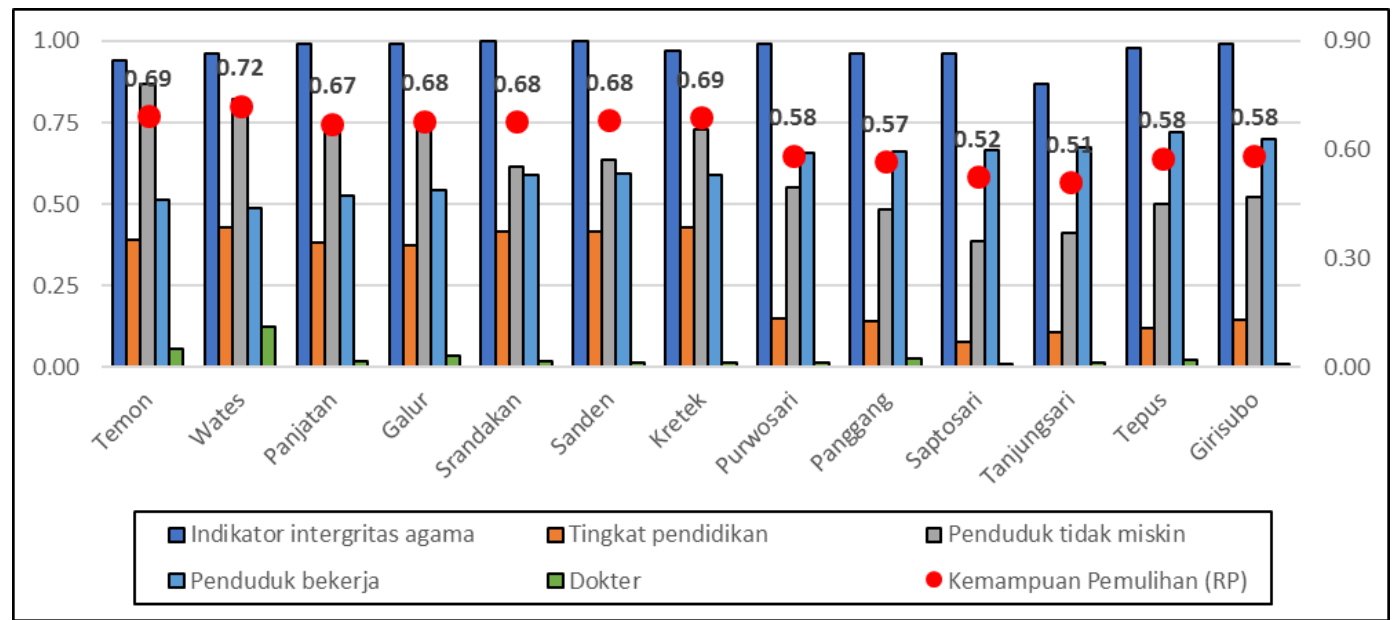

Sumber: Penulis, 2021

Gambar 6. Nilai indikator ketangguhan kemampuan pemulihan

Tingkat pendidikan yang dimiliki oleh penduduk di suatu wilayah mempunyai pengaruh yang positif terhadap ketangguhan terhadap bencana dari wilayah itu sendiri. Frankenberg et al. (2013) menemukan bahwa orang-orang dengan pendidikan yang tinggi memiliki kemampuan bertahan hidup yang lebih tinggi setelah terhantam bencana. Hal ini dikarenakan mereka memiliki jaringan atau koneksi yang lebih banyak serta memiliki ketahanan mental yang lebih kuat dibandingkan dengan orang yang berpendidikan rendah. Selain itu, melalui proses pendidikan, seseorang bisa mendapatkan pengetahuan, keterampilan dan juga sudut pandang sebagai persiapan untuk menghadapi sebuah bencana di masa yang akan datang (Hoffmann \& Blecha, 2020). Lebih jauh, orang-orang berpendidikan tinggi mempunyai reaksi yang lebih cepat ketika ada peringatan dini tentang terjadinya suatu bencana (Morrow, 2008; Sharma et al., 2013).

Indikator lain yang juga berpengaruh dalam menentukan nilai ketangguhan dimensi kemampuan pemulihan adalah jumlah penduduk miskin. Semakin banyak jumlah 
penduduk miskin di suatu wilayah, maka semakin rendah kemampuan wilayah tersebut untuk segera pulih setelah kejadian bencana. Untuk indikator ini, kecamatan pesisir di Kabupaten Gunungkidul juga mempunyai nilai yang lebih rendah daripada kecamatan lain. Jumlah penduduk miskin pada kecamatan pesisir di kabupaten ini lebih banyak daripada yang ada di kecamatan lain dalam penelitian ini.

Penduduk miskin merupakan salah satu kelompok yang paling rentan terhadap dampak negatif yang ditimbulkan oleh suatu bencana (Hallegatte et al., 2010). Mereka berisiko lebih besar mengalami kematian dan kerugian dalam suatu kejadian bencana. Selain itu, mereka juga seringkali kurang mendapatkan perhatian dalam penyaluran bantuan (Norris, 2008; Tobin \& Whitefor, 2002). Padahal, penduduk miskin tidak mempunyai kemampuan ekonomi yang memadai untuk menghadapi sebuah bencana sehingga mereka sangat bergantung pada bantuan dari pemerintah (Rentschler, 2013).

\section{SIMPULAN DAN SARAN}

Analisis ketangguhan dalam studi ini menemukan bahwa kecamatan-kecamatan di kawasan pesisir selatan Provinsi DIY mempunyai ketangguhan wilayah terhadap bencana tsunami yang masih rendah. Dari 13 kecamatan yang diukur, 12 di antaranya termasuk dalam kecamatan dengan nilai ketangguhan sangat rendah hingga rendah (nilai ketangguhan 0-0,50); dan hanya satu kecamatan yang memiliki ketangguhan terhadap bencana tsunami dalam level sedang. Nilai ketangguhan kecamatan-kecamatan di wilayah ini ada di rentang 0,16-0,62; dalam skala nilai ketangguhan 0-1. Kecamatan yang mempunyai nilai ketangguhan yang paling tinggi adalah Kecamatan Wates Kabupaten Kulon Progo. Sedangkan kecamatan dengan nilai ketangguhan terendah adalah Kecamatan Girisubo Kabupaten Gunungkidul.

Beberapa indikator ditemukan berpengaruh dalam menentukan tinggi rendahnya nilai suatu dimensi ketangguhan. Jaringan jalan adalah indikator berpengaruh dalam menentukan ketangguhan dimensi kapasitas lokasi (OC). Kemudian, pada dimensi kemampuan masyarakat untuk bertahan (IS), indikator yang berpengaruh adalah kepadatan penduduk. Sedangkan pada dimensi ketangguhan kemampuan pemulihan (RP), ada dua indikator yang cukup berpengaruh yaitu tingkat pendidikan dan jumlah penduduk miskin.

Risiko bencana tsunami di pesisir selatan Provinsi DIY merupakan ancaman yang perlu diperhatikan oleh pemerintah, baik itu pemerintah kabupaten maupun provinsi. Berdasarkan hasil temuan dalam penelitian ini, beberapa upaya perlu dilakukan oleh pemerintah untuk meningkatkan ketangguhan terhadap bencana tsunami di wilayah ini. Upaya pertama yang perlu untuk dilakukan adalah peningkatan kualitas dan kuantitas infrastruktur jalan sebagai prasarana pendukung proses evakuasi dan penyaluran bantuan ketika terjadi bencana. Kemudian, upaya lain yang juga perlu dilakukan pemerintah adalah meningkatkan kesadaran masyarakat terhadap resiko bencana tsunami. Peningkatan kesadaaran ini diperlukan agar penduduk bisa mempersiapkan diri dan keluarganya untuk menghadapi resiko terjadinya bencana di masa mendatang. Lalu, upaya lain yang juga harus dilakukan adalah peningkatan kualitas pendidikan dan pengembangan kegiatan ekonomi bagi penduduk di wilayah pesisir. 
Analisis pengukuran ketangguhan dalam studi ini merupakan metode yang baru. Oleh karena itu, aplikasi metode ini di lokasi lain perlu dilakukan untuk menjadi tolok ukur relevansi hasil pengukuran dengan kenyataan yang ada. Selain itu, aplikasi metode ini juga bisa dikembangkan dengan menambah indikator-indikator lain yang terkait dengan ketangguhan suatu wilayah. Hal ini bertujuan untuk memberikan gambaran ketangguhan bencana secara lebih komprehensif.

\section{DAFTAR PUSTAKA}

[1] Badan Nasional Penanggulangan Bencana (BNPB). (2016). Risiko Bencana Indonesia. Jakarta: BNPB.

[2] Badan Nasional Penanggulangan Bencana (BNPB). (2019a). Indeks Risiko Bencana Indonesia. Jakarta: BNPB.

[3] Badan Nasional Penanggulangan Bencana (BNPB). (2019b). Katalog Desa/Kelurahan Rawan Tsunami: Kelas Bahaya Tinggi dan Sedang. Jakarta: BNPB.

[4] Bahena-Ayala, R., Arreguín-Cortés, F. I., \& Cervantes-Jaimes, C. E. (2021). Assessing resilience of cities to hydrometeorological hazards. Tecnología y Ciencias Del Agua, 12(1), 192-260. https://doi.org/10.24850/j-tyca-2021-01-06

[5] Béné, C. (2013, September). Towards a Quantifiable Measure of Resilience. Institute of Development Studies. https://onlinelibrary.wiley.com/doi/pdf/10.1111/j.20400209.2013.00434.x

[6] Benson, C., \& Clay, E. J. (2004). Understanding the Economic and Financial Impacts of Natural Disasters. Disaster Risk Management series; no. 4. Washington, DC: World Bank. (c) World https://openknowledge.worldbank.org/handle/10986/15025 License: CC BY 3.0 IGO.

[7] Buikstra, E., Ross, H., King, C. A., Baker, P. G., Hegney, D., McLachlan, K., \& Rogers-Clark, C. (2010). The components of resilience-Perceptions of an Australian rural community. Journal of Community Psychology, 38(8), 975-991. https://doi.org/10.1002/jcop.20409

[8] Cai, H., Lam, N., Zou, L., Qiang, Y., \& Li, K. (2016). Assessing Community Resilience to Coastal Hazards in the Lower Mississippi River Basin. Water, 8(2), 46. https://doi.org/10.3390/w8020046

[9] Cutter, S. L., Burton, C. G., \& Emrich, C. T. (2010). Disaster Resilience Indicators for Benchmarking Baseline Conditions. Journal of Homeland Security and Emergency Management, 7(1), 1-22. https://doi.org/10.2202/1547-7355.1732

[10] Frankenberg, E., Sikoki, B., Sumantri, C., Suriastini, W., \& Thomas, D. (2013). Education, Vulnerability, and Resilience after a Natural Disaster. Ecology and Society, 18(2), 1-23. https://doi.org/10.5751/es-05377-180216

[11] Hallegatte, S., Henriet, F., Patwardhan, A., Narayanan, K., Ghosh, S., Karmakar, S., Patnaik, U., Abhayankar, A., Pohit, S., Corfee-Morlot, J., Herweijer, C., Ranger, N., Bhattacharya, S., Bachu, M., Priya, S., Dhore, K., Rafique, F., Mathur, P. \& Naville, N. (2010), "Flood Risks, Climate Change Impacts and Adaptation Benefits in Mumbai: An Initial Assessment of Socio-Economic Consequences of Present and Climate Change Induced Flood Risks and of Possible Adaptation Options", OECD Environment Working Papers, No. 27, OECD Publishing, Paris, https://doi.org/10.1787/5km4hv6wb434-en

[12] Hoffmann, R., \& Blecha, D. (2020). Education and Disaster Vulnerability in Southeast Asia: Evidence and Policy Implications. Sustainability, 12(4), 1401. https://doi.org/10.3390/su 12041401 
[13] Imperiale, A. J., \& Vanclay, F. (2016). Experiencing local community resilience in action: Learning from post-disaster communities. Journal of Rural Studies, 47, 204219. https://doi.org/10.1016/j.jrurstud.2016.08.002

[14] Kongko, W., \& Hidayat, R. (2014). Earthquake-Tsunami in South Jogjakarta Indonesia: Potential, Simulation Models, and Related Mitigation Efforts. IOSR Journal of Applied Geology and Geophysics, 2(3), 18-22. https://doi.org/10.9790/0990-0231822

[15] Kusumastuti, R. D., Viverita, Husodo, Z. A., Suardi, L., \& Danarsari, D. N. (2014). Developing a resilience index towards natural disasters in Indonesia. International Journal of Disaster Risk Reduction, 10, 327-340. https://doi.org/10.1016/j.ijdrr.2014.10.007

[16] Levy, J. K., \& Gopalakrishnan, C. (2005). Promoting Disaster-resilient Communities: The Great Sumatra-Andaman Earthquake of 26 December 2004 and the Resulting Indian Ocean Tsunami. International Journal of Water Resources Development, 21(4), 543-559. https://doi.org/10.1080/07900620500363297

[17] Marfai, M. A., Sunarto, Khakim, N., Fatchurohman, H., Cahyadi, A., Wibowo, Y. A., \& Rosaji, F. S. C. (2019). Tsunami hazard mapping and loss estimation using geographic information system in Drini Beach, Gunungkidul Coastal Area, Yogyakarta, Indonesia. E3S Web of Conferences, 76, 03010. https://doi.org/10.1051/e3sconf/20197603010

[18] Morrow, B. 2008. "Community Resilience: A Social Justice Perspective." CARRI Research Report 4. Oak Ridge: Community and Regional Resilience Institute.

[19] National Emergency Management Committee. (2009, Desember). National Strategy for Disaster Resilience: Building Our Nation's Resilience to Disasters. https://www.preventionweb.net/files/18017_nationalstrategydisasterresilience.pdf

[20] Norris, F. H., Stevens, S. P., Pfefferbaum, B., Wyche, K. F., \& Pfefferbaum, R. L. (2008). Community Resilience as a Metaphor, Theory, Set of Capacities, and Strategy for Disaster Readiness. American Journal of Community Psychology, 41(12), 127-150. https://doi.org/10.1007/s10464-007-9156-6

[21] Oktari, R. S., Syamsidik, Idroes, R., Sofyan, H., \& Munadi, K. (2020). City Resilience towards Coastal Hazards: An Integrated Bottom-Up and Top-Down Assessment. Water, 12(10), 2823. https://doi.org/10.3390/w12102823

[22] Paramesti, C. A. (2011). "Kesiapsiagaan Masyarakat Kawasan Teluk Pelabuhan Ratu terhadap Bencana Gempa Bumi dan Tsunami." Jurnal Perencanaan Wilayah dan Kota 113-128

[23] Parsons, M., Glavac, S., Hastings, P., Marshall, G., McGregor, J., McNeill, J., Morley, P., Reeve, I., \& Stayner, R. (2016). Top-down assessment of disaster resilience: A conceptual framework using coping and adaptive capacities. International Journal of Disaster Risk Reduction, 19, 1-11. https://doi.org/10.1016/j.ijdrr.2016.07.005

[24] Prasetya, T., \& Imamura, F. (2010). Numerical simulation for the assessment of tsunami scenarios in southern yogyakarta, central java island, indonesia. Bulletin of the International Institute of Seismology and Earthquake Engineering, 44, 121-126.

[25] Pushpalal, D., \& Suzuki, A. (2020). A New Methodology for Measuring Tsunami Resilience Using Theory of Springs. Geosciences, 10(11), 469. https://doi.org/10.3390/geosciences10110469

[26] Rifat, S. A. A., \& Liu, W. (2020). Measuring Community Disaster Resilience in the Conterminous Coastal United States. ISPRS International Journal of GeoInformation, 9(8), 469. https://doi.org/10.3390/ijgi9080469 
[27] Rentschler, J. E. (2013). Why Resilience Matters: The Poverty Impacts of Disasters. Policy Research Working Paper; No. 6699. World Bank, Washington, DC.

[28] Sharma, U., Patwardhan, A., \& Patt, A. G. (2013). Education as a Determinant of Response to Cyclone Warnings: Evidence from Coastal Zones in India. Ecology and Society, 18(2), 1-15. https://doi.org/10.5751/es-05439-180218

[29] Syam, A. (2016). "Kelayakan Jalur Evakuasi Tsunami di Kecamatan Padang Utara Kota Padang." Jurnal Kepemimpinan dan Kepengurusan Sekolah 11-15

[30] Tobin, G. A., \& Whiteford, L. M. (2002). Community Resilience and Volcano Hazard: The Eruption of Tungurahua and Evacuation of the Faldas in Ecuador. Disasters, 26(1), 28-48. https://doi.org/10.1111/1467-7717.00189

[31] UNISDR. (2009, Mei). UNISDR Terminology on Disaster Risk Reduction. https://www.unisdr.org/files/7817_UNISDRTerminologyEnglish.pdf

[32] UNISDR. (2015, Maret). The Sendai Framework for Disaster Risk Reduction 20152030. https://www.preventionweb.net/files/43291_sendaiframeworkfordrren.pdf

[33] Xu, W., Xiang, L., \& Proverbs, D. (2020). Assessing Community Resilience to Urban Flooding in Multiple Types of the Transient Population in China. Water, 12(10), 2784. https://doi.org/10.3390/w12102784

[34] Yavuz, C., Kentel, E., \& Aral, M. M. (2020). Tsunami risk assessment: economic, environmental and social dimensions. Natural Hazards, 104(2), 1413-1442. https://doi.org/10.1007/s11069-020-04226-y 